\title{
Bipolar versus monopolar technique for palliative transurethral prostate resection
}

Dirk P.J. Michielsen ${ }^{1}$, Danny Coomans², Benedikt Engels³ ${ }^{3}$ Johan G. Braeckman ${ }^{1}$

1Department of Urology, University Hospital - Free University of Brussels, Belgium
2Department of Biostatistics and Medical Informatics, Faculty of Medicine and Pharmacy,
University Hospital - Free University of Brussels, Belgium
32Department of Radiotherapy, University Hospital - Free University of Brussels, Belgium

Submitted: 13 January 2010

Accepted: 29 March 2010

Arch Med Sci 2010; 6, 5: 780-786

DOI: 10.5114/aoms.2010.17095

Copyright (c) 2010 Termedia \& Banach

\author{
Corresponding author: \\ Dirk P.J. Michielsen, MD, PhD \\ Department of Urology \\ University Hospital - \\ Free University of Brussels \\ Laarbeeklaan 101 \\ 1090 Brussels, Belgium \\ Phone: +32 24777900 \\ Fax: +32 24776818 \\ E-mail: \\ dirk.michielsen@uzbrussel.be
}

\section{Abstract}

Introduction: The aim was to evaluate the postoperative morbidity and outcome of palliative endoscopic resections for relief of infravesical obstruction in prostate cancer patients with hormone deprivation therapy, and to investigate the added value of bipolar technology over conventional monopolar resections.

Material and methods: A retrospective study was performed on 70 patients with prostate cancer under hormone deprivation therapy undergoing 75 endoscopic procedures, by either monopolar or bipolar technology, between August 2005 and March 2009 at a single institution. The analysis used outpatient, inpatient, and operative records, and observations of electrolyte changes in the serum, postoperative morbidity, and the overall results of palliative endoscopic resections. Preoperative cancer stages and grades were compared with the pathological findings after surgery. Postoperative outcome and complications of conventional monopolar and bipolar technology were compared.

Results: Over a period of 44 months, 34 conventional monopolar resections were performed in 32 patients and 41 bipolar resections in 38 patients. Patients' profiles regarding age, initial cancer stage and grade, resection weight, resection speed, catheterization time, and hospital stay were similar in both groups. No statistically significant difference was observed in sodium drop $(p=0.802)$, clot retention $(p=0.565)$, or urinary retention $(p=0.292)$. The overall success rate in relieving obstruction leading to spontaneous voiding was $77 \%$. While $38 \%$ of the patients had a high grade tumour at diagnosis, $79 \%$ were found to be high grade after the endoscopic resection $(p<0.0001)$.

Conclusions: Palliative endoscopic transurethral resection is an acceptable and safe adjunctive surgical treatment for voiding disorders in prostate cancer patients. Bipolar technology offers no substantial benefit over conventional monopolar technology.

Key words: prostate, prostate cancer, transurethral resection.

\section{Introduction}

Monopolar transurethral resection of the prostate (TURP) is the gold standard for the operative management of benign prostatic hyperplasia (BPH) [1].

New techniques must be compared with the known efficacy of monopolar TURP [2]. The risk of complications such as transurethral resection (TUR) syndrome, bleeding, and clot retention associated with conventional monopolar resections discourages some patients from choosing an endoscopic procedure. 
Bipolar resection of the prostate is based on a slightly different technological concept. By incorporating both the active and return poles on the same electrode [3], a conductive fluid medium (normal saline) instead of the conventional nonconductive irrigation fluid (glycine, sorbitol, and mannitol) can be used.

The peri- and postoperative morbidity as well as the final outcome of bipolar resections with the Gyrus PlasmaKinetic and the Olympus TURIS systems was evaluated in several randomized controlled trials [4]. All trials supported the conclusion that bipolar technology provides a similar clinical efficacy compared to that of monopolar transurethral resection of the prostate [4]. The lower risk of peri- and postoperative morbidity regarding TUR syndrome and clot retention however does favour the bipolar technology [5].

We retrospectively evaluated this peri- and postoperative morbidity using both techniques in patients with urinary obstruction due to prostate cancer.

\section{Material and methods}

A retrospective analysis of 75 endoscopic procedures in 70 patients for relief of obstructive voiding difficulties and retention due to prostate cancer was performed at a single university institution between August 2005 and March 2009. Outpatient records, inpatient charts, and operative reports were reviewed.

Electrolyte changes, postoperative complications, and clinical outcome were selected as data points of special interest in order to compare the two slightly different pieces of operative equipment, i.e. the monopolar technique (TURP) and bipolar technique (TURIS).

All palliative endoscopic resections were performed by two staff urologists, both familiar with the two types of equipment. A standard Olympus resectoscope and an Olympus UES-40 SurgMaster electrical current generator were used for both techniques. Monopolar TURP was carried out with a standard $24 \mathrm{Fr}$ resectoscope and standard loops using $175 \mathrm{~W}$ cutting power and $75 \mathrm{~W}$ coagulation power. Bipolar TURIS was performed using a $24 \mathrm{Fr}$ resectoscope with the bipolar electrode set at $270 \mathrm{~W}$ for cutting and $75 \mathrm{~W}$ for coagulation. All procedures were performed with intermittent glycine 5\% (monopolar TURP) or saline $0.9 \%$ (bipolar TURIS) irrigation using general or spinal anaesthesia. An average amount of 12 litres/procedure was used.

Both urologists used the same resection technique. Palliative resection was defined as a limited resection to create a channel permitting better urinary flow. In contrast with standard endoscopic resection for $\mathrm{BPH}$, resection to the depth of the prostatic capsule was not attempted. All resected tissue was weighed and submitted to the pathologist for review. At the end of the procedure, a $22 \mathrm{Fr} 3$-way Foley catheter with a closed drainage system was inserted. All patients were treated postoperatively with continuous saline bladder irrigation until bleeding ended. After discharge, patients were reassessed at three-month intervals.

All statistical tests performed were two-sided and at the $5 \%$ level of performance. The two groups were compared using the independent $T$-test. The incidence of complications such as TUR syndrome, clot retention, and urinary retention were determined by Fisher's exact test. The $p$-values obtained were similar to the $\chi^{2}$ test with continuity correction. SPSS version 17.0 was used to perform the tests.

\section{Results}

A total of 70 patients underwent 75 endoscopic procedures between August 2005 and March 2009. Their mean age was $76 \pm 9$ years (range 61 to 93 years). The mean time from cancer diagnosis to endoscopic resection was $56.7 \pm 52.5$ months (range 3 to 210 months). The initial oncological parameters are listed in Table I. In 68 of the 70 patients, the initial diagnosis of prostate cancer was made in our institution. T1 prostate cancer was found in $18 \%$, T2 prostate cancer in 22\%, T3 prostate cancer in $53 \%$, and $\mathrm{T} 4$ prostate cancer in $7 \%$. Regarding initial grading, 12\% had well-differentiated, 50\% moderately differentiated, and $38 \%$ poorly differentiated prostate cancer. Twenty-two of the 68 men had metastatic disease as documented by plain X-ray and bone scan at the time of diagnosis.

Table I. Initial oncological parameters

\begin{tabular}{|lccc|}
\hline $\begin{array}{c}\text { Variables } \\
\text { Stage }\end{array}$ & $\begin{array}{c}\text { Monopolar } \\
\text { TURP } \\
N(\%)\end{array}$ & $\begin{array}{c}\text { Bipolar } \\
\text { TURIS } \\
N(\%)\end{array}$ & $\begin{array}{c}\text { Total } \\
N(\%)\end{array}$ \\
\hline T1 & $6(19)$ & $6(17)$ & $12(18)$ \\
\hline T2 & $5(16)$ & $10(28)$ & $15(22)$ \\
\hline T3 & $19(59)$ & $17(47)$ & $36(53)$ \\
\hline T4 & $2(6)$ & $3(8)$ & $5(7)$ \\
\hline G-4 & $4(17)$ & $3(9)$ & $7(12)$ \\
\hline $5-7$ & $12(50)$ & $17(50)$ & $29(50)$ \\
\hline $8-10$ & $8(33)$ & $14(41)$ & $22(38)$ \\
\hline Bone & $11(34)$ & $11(31)$ & $22(32)$ \\
metastases & & & \\
\hline
\end{tabular}

TURP - transurethral resection of prostate, TURIS - transurethral resection of prostate in saline, $N$-number 
The initial treatments are listed in Table II. Of the 70 patients, 16 (23\%) patients received external beam radiation therapy. In 7 patients this was combined with hormonal treatment with luteinizing hormone-releasing hormone during 3 years. Fortyfour $(63 \%)$ patients had hormonal treatment for prostate cancer from the beginning (luteinizing hormone-releasing hormone in 38 patients and bilateral subcapsular orchiectomy in 6 patients). In 10 patients, active surveillance was preferred.

At the time of resection, all patients had urinary retention while under hormonal treatment. PSA values are listed in Table III. Thirty-four palliative resections were carried out in 32 patients by

Table II. Initial therapeutic approach to prostate cancer

\begin{tabular}{|lccc|}
\hline Variables & $\begin{array}{c}\text { Monopolar } \\
\text { TURP } \\
N(\%)\end{array}$ & $\begin{array}{c}\text { Bipolar } \\
\text { TURIS } \\
N(\%)\end{array}$ & $\begin{array}{c}\text { Total } \\
N(\%)\end{array}$ \\
& $5(16)$ & $5(13)$ & $10(14)$ \\
\hline Active surveillance & $5(16)$ & $4(11)$ & $9(13)$ \\
\hline Radiotherapy & $2(6)$ & $5(13)$ & $7(10)$ \\
\hline $\begin{array}{l}\text { Radiotherapy and } \\
\text { years hormonal }\end{array}$ & & & \\
treatment & $20(62)$ & $24(63)$ & $44(63)$ \\
\hline Hormonal treatment & & & \\
\hline
\end{tabular}

TURP - transurethral resection of prostate, TURIS - transurethral resection of prostate in saline, $\mathrm{N}$ - number

Table III. PSA value at diagnosis, before and after endoscopic resection

\begin{tabular}{|lcc|}
\hline Variables & $\begin{array}{c}\text { Monopolar } \\
\text { TURP }( \pm \text { SD })\end{array}$ & $\begin{array}{c}\text { Bipolar } \\
\text { TURIS }( \pm \text { SD })\end{array}$ \\
\hline $\begin{array}{l}\text { PSA at diagnosis } \\
{[\mathrm{ng} / \mathrm{ml}]}\end{array}$ & $70.35( \pm 118.43)$ & $78.59( \pm 220.99)$ \\
\hline $\begin{array}{l}\text { PSA before } \\
\text { endoscopic resection }\end{array}$ & $50.72( \pm 73.65)$ & $128.16( \pm 274.80)$ \\
\hline $\begin{array}{l}\text { PSA after } \\
\text { endoscopic resection }\end{array}$ & $93.40( \pm 179.72)$ & $71.92( \pm 142.80)$ \\
\hline
\end{tabular}

TURP - transurethral resection of prostate, TURIS - transurethral resection of prostate in saline conventional monopolar technique. In 38 patients, 41 bipolar resections in saline were performed. Table IV compares the preoperative and perioperative statistics. Average preoperative prostatic volume measured by transrectal ultrasound was $58.6 \pm 16.5 \mathrm{~g}$ in the conventional monopolar group and $51.0 \pm 16.8 \mathrm{~g}$ in the bipolar group. Table $\mathrm{V}$ shows that a vast majority of patients had spinal anaesthesia (91\% in the conventional monopolar group, $78 \%$ in the bipolar group). Of all perioperative parameters, only longer resection time was statistically significant in the bipolar group (40.0 $\pm 15.2 \mathrm{~min}$ vs. $49.1 \pm 20.5 \mathrm{~min})(P=0.03)$. However, after correction with respect to the weight of resected prostatic tissue, no statistically significant difference in resection speed between the two groups was observed $(0.4 \pm 0.3 \mathrm{~g} / \mathrm{min}$ vs. $0.4 \pm 0.3 \mathrm{~g} / \mathrm{min}$ ). Tables $\mathrm{VI}$ and $\mathrm{VII}$ show the changes in electrolytes before and after resection. No statistically significant changes were observed in haemoglobin, sodium, potassium, or chloride.

Postoperatively there were no cases of TUR syndrome in either group (Table IX). The indwelling catheter was removed after $1.6 \pm 0.9$ days in the conventional monopolar group and $2.0 \pm 2.5$ days in the bipolar group ( $p=0.342)$ (Table IV).

Seven palliative resections $(9.3 \%)$ were complicated with postoperative clot retention, 2 in the conventional monopolar group and 5 in the bipolar resection group ( $p=0.565$ ) (Table IX).

Palliative endoscopic resection was successful in $77 \%$ of the patients. Urinary retention occurred after 5 conventional monopolar resections (15\%) and 11 bipolar resections (27\%) $(p=0.292)$. A longterm indwelling catheter was necessary for 16 patients (23\%) (Table IX).

Patients were discharged from the hospital after respectively $4.6 \pm 2.2$ days in the conventional and $5.8 \pm 4.6$ days in the bipolar group (Table IV).

Postoperative pathological evaluation was available in 66 (94.4\%) patients. In 6 procedures there was only benign prostate tissue in the resected parts. Cancer was found in 65 procedures (62 patients) (Table VIII), well-differentiated in 3\%

Table IV. Characteristics of two groups

\begin{tabular}{|lcccc|}
\hline Variables & $\begin{array}{c}\text { Monopolar TURP } \\
\text { mean }( \pm \text { SD })\end{array}$ & $\begin{array}{c}\text { Bipolar TURIS } \\
\text { mean }( \pm \text { SD) }\end{array}$ & $p$-value & $95 \%$ confidence interval \\
\hline Age [years] & $75.7( \pm 8.3)$ & $75.6( \pm 8.8)$ & 0.941 & $(-3.930,4.230)$ \\
\hline Prostate $[\mathrm{ml}]$ & $58.6( \pm 16.5)$ & $51.0( \pm 16.8)$ & 0.517 & $(-33.976,18.776)$ \\
\hline Operative time [min] & $40.0( \pm 15.2)$ & $49.1( \pm 20.5)$ & 0.032 & $(0.785,17.374)$ \\
\hline Resection weight [g] & $16.86( \pm 10.6)$ & $17.30( \pm 10.3)$ & 0.858 & $(-5.361,4.476)$ \\
\hline Resection speed $[\mathrm{g} / \mathrm{min}]$ & $0.4( \pm 0.3)$ & $0.4( \pm 0.3)$ & 0.992 & $(-0.159,0.157)$ \\
\hline Catheterization time [days] & $1.6( \pm 0.9)$ & $2.0( \pm 2.5)$ & 0.342 & $(-0.464,1.321)$ \\
\hline Hospital stay [days] & $4.6( \pm 2.2)$ & $5.8( \pm 4.6)$ & 0.179 & $(-0.543,2.855)$ \\
\hline
\end{tabular}

TURP - transurethral resection of prostate, TURIS - transurethral resection of prostate in saline, SD - standard deviation 
(2 patients), moderately differentiated in 18\% (11 patients) and poorly differentiated in 79\% (49 patients). While $38 \%$ of the patients had a high grade tumour at diagnosis, $79 \%$ were found to have high grade prostate cancer at the time of the resection.

Postoperative PSA analysis 3 months after surgery increased from a mean value of $50.72 \mathrm{ng} / \mathrm{ml}$ before the surgery to a mean of $93.40 \mathrm{ng} / \mathrm{ml}$ in the conventional monopolar group (Table III) $(p=0.372$ ). Over the same period in the bipolar group, there was a PSA decline after surgery from $128.16 \mathrm{ng} / \mathrm{ml}$ to $71.92 \mathrm{ng} / \mathrm{ml}(p=0.350)$.

\section{Discussion}

Urinary retention is a common complication in patients with locally advanced prostate cancer, with an incidence of $13 \%$ to $20 \%$ [6-7]. The first step is usually initiation of hormone deprivation treatment in combination with an indwelling catheter [8].

Table V. Anaesthesia

\begin{tabular}{|lcc|}
\hline Variables & $\begin{array}{c}\text { Monopolar } \\
\text { TURP, } N(\%)\end{array}$ & $\begin{array}{c}\text { Bipolar } \\
\text { TURIS, } N(\%)\end{array}$ \\
\hline Spinal anaesthesia & $32(91)$ & $32(78)$ \\
\hline General anaesthesia & $3(9)$ & $9(22)$ \\
\hline
\end{tabular}

TURP - transurethral resection of prostate, TURIS - transurethral resection of prostate in saline, $\mathrm{N}$-number
Ultrasonic volume determinations in patients with prostate cancer treated by hormonal deprivation therapy showed a $50 \%$ reduction of the gland size in the first month [9], continuing for nine months after orchiectomy. Fleischmann and Catalona reported a $68 \%$ response rate after hormonal treatment for urinary retention in 35 patients with advanced prostate cancer [10]. Unfortunately, an indwelling catheter was necessary for 21 to 60 days in $46 \%$ of the patients. Thomas et al. achieved an $83 \%$ success rate in 12 patients after 1 month [8].

Hormonal deprivation therapy is not limited to orchiectomy. Varenhorst and Alund were successful in relieving urethral obstruction by carcinoma of the prostate in $65 \%$ of patients treated by orchiectomy, cyproterone acetate, or oestrogens [11].

Hormonally deprived patients with acute or persisting urinary retention are initially helped with a transurethral or suprapubic bladder catheter. Since long-term catheter drainage is hazardous, patients who are fit for surgery are considered ideal candidates for a palliative endoscopic prostate resection. In this study, all patients were already on hormone deprivation therapy when the urinary retention occurred.

Palliative or channel TUR has the advantage of enabling restored micturition but is not free from complications such as stress incontinence and rapid regrowth of obstructive prostate cancer requiring

Table VI. Summary of laboratory results

\begin{tabular}{|c|c|c|c|}
\hline Variables & Preoperation, mean $( \pm S D)$ & Postoperation, mean ( \pm SD) & Difference \\
\hline \multicolumn{4}{|l|}{ Monopolar TURP } \\
\hline Haemoglobin [mg/dl] & $13.1( \pm 1.9)$ & $11.9( \pm 1.7)$ & -1.2 \\
\hline Sodium $[\mathrm{mmol} / \mathrm{l}]$ & $140.9( \pm 3.2)$ & $139.2( \pm 2.7)$ & -1.7 \\
\hline Potassium [mmol/l] & $4.2( \pm 0.5)$ & $4.1( \pm 0.4)$ & -0.1 \\
\hline Chloride $[\mathrm{mmol} / \mathrm{l}]$ & $104.7( \pm 3.1)$ & $105.1( \pm 3.2)$ & +0.5 \\
\hline \multicolumn{4}{|l|}{ Bipolar TURIS } \\
\hline Haemoglobin [mg/dl] & $12.8( \pm 2.0)$ & $11.6( \pm 2.1)$ & -1.3 \\
\hline Sodium $[\mathrm{mmol} / \mathrm{l}]$ & $141.9( \pm 3.0)$ & $140.0( \pm 2.9)$ & -1.9 \\
\hline Potassium [mmol/l] & $4.1( \pm 0.4)$ & $4.0( \pm 0.4)$ & -0.1 \\
\hline Chloride $[\mathrm{mmol} / \mathrm{l}]$ & $105.1( \pm 2.9)$ & $105.5( \pm 2.9)$ & +0.4 \\
\hline
\end{tabular}

TURP - transurethral resection of prostate, TURIS - transurethral resection of prostate in saline, SD - standard deviation

Table VII. Chemical and haematological parameters

\begin{tabular}{|lcccc|}
\hline Variables & $\begin{array}{c}\text { Monopolar TURP } \\
\text { mean }( \pm \text { SD) }\end{array}$ & $\begin{array}{c}\text { Bipolar TURIS } \\
\text { mean }( \pm \text { SD) }\end{array}$ & $p$-value & $95 \%$ confidence interval \\
\hline Haemoglobin $[\mathrm{mg} / \mathrm{dl}]$ & $-1.2( \pm 0.9)$ & $-1.3( \pm 1.3)$ & 0.606 & $(-0.629,0.369)$ \\
\hline Sodium $[\mathrm{mmol} / \mathrm{l}]$ & $-1.7( \pm 3.1)$ & $-1.9( \pm 2.6)$ & 0.802 & $(-1.491,1.156)$ \\
\hline Potassium $[\mathrm{mmol} / \mathrm{l}]$ & $-0.1( \pm 0.4)$ & $-0.1( \pm 0.3)$ & 0.331 & $(-0.086,0.252)$ \\
\hline Chloride $[\mathrm{mmol} / \mathrm{l}]$ & $0.5( \pm 2.7)$ & $0.4( \pm 2.5)$ & 0.895 & $(-1.288,1.127)$ \\
\hline
\end{tabular}

TURP - transurethral resection of prostate, TURIS - transurethral resection of prostate in saline, SD - standard deviation 
Table VIII. Histological data after endoscopic resection

\begin{tabular}{|lccc|}
\hline Variables & $\begin{array}{c}\text { Monopolar } \\
\text { TURP } \\
N(\%)\end{array}$ & $\begin{array}{c}\text { Bipolar } \\
\text { TURIS } \\
N(\%)\end{array}$ & $\begin{array}{c}\text { Total } \\
N(\%)\end{array}$ \\
\hline Grade & & & \\
\hline $2-4$ & $1(3)$ & $1(3)$ & $2(3)$ \\
\hline $5-7$ & $8(28)$ & $3(9)$ & $11(18)$ \\
\hline $8-10$ & $20(69)$ & $29(88)$ & $49(79)$ \\
\hline
\end{tabular}

TURP - transurethral resection of prostate, TURIS - transurethral resection of prostate in saline, $\mathrm{N}$ - number

Table IX. Complications

\begin{tabular}{|lccc|}
\hline Variables & $\begin{array}{c}\text { Monopolar } \\
\text { TURP } \\
N(\%)\end{array}$ & $\begin{array}{c}\text { Bipolar } \\
\text { TURIS } \\
N(\%)\end{array}$ & $p$ \\
\hline TUR syndrome & $0(0)$ & $0(0)$ & 1.000 \\
\hline Clot retention & $2(6)$ & $5(12)$ & 0.565 \\
\hline Urinary retention & $5(15)$ & $11(27)$ & 0.292 \\
\hline
\end{tabular}

TURP - transurethral resection of prostate, TURIS - transurethral resection of prostate in saline, TUR - transurethral resection

repeated surgery [12]. Mazur and Thompson report a success rate of $79 \%$ [12]. In our study a success rate of $77 \%$ was achieved. Palliative endoscopic resection failed in 16 patients (23\%), demanding a long-term suprapubic or transurethral catheter as a final solution.

Our re-operation rate was $6 \%$. A factor in reintervention was a reoccurring obstruction due to ongoing local tumour progression. Crain et al. reported $29 \%$ of patients requiring additional procedures [13], including surgical intervention for haemorrhage and clot retention. Our incidence of clot retention was $9.3 \%$, but all cases could be managed conservatively.

A potential drawback of palliative endoscopic transurethral resection of a malignant gland is that this is technically more difficult. The prostatic urethra may be rigid and both the verumontanum and external sphincter hard to identify. This leads to a higher risk of incontinence. External radiotherapy that had been applied in some patients causes radiation effects that may contribute to the complication rate.

Palliative endoscopic resections have been criticized by Engelhardt and Riedl [14], as resection and venous propagation of tumour cells may enhance further dissemination of the disease. Such a possible negative impact on progression has been demonstrated in several studies. Fadlon et al. detected circulating prostate cancer cells in the serum of patients after prostate manipulations [15]. Clinical observations in patients with high grade cancer or progressive cancer showed higher postoperative rates of metastasis [16-19]. Furthermore, some survival benefit was observed when palliative endoscopic resection was avoided [14] Therefore, Hübner et al. promotes intraprostatic stenting in locally advanced prostate cancer and urinary obstruction [20]. Our personal experience with prostatic stenting is disappointing and corresponds with the results and the high rates of complications reported in the literature [21]. Our goal in hormonal refractory prostate cancer patients is for improved quality of life rather than for quantity of months of survival.

Transurethral resection of the prostate with conventional monopolar loops remains the gold standard for treatment of symptomatic obstructive prostatic hypertrophy [22]. The current passes from the active electrode on the monopolar resectoscope through the patient's body to the return plate. This can provoke deep tissue heating, stimulation of underlying nerves or muscles, burning wounds at the site of the return electrode and malfunction of cardiac pacemakers [23]. The risk of complications such as bleeding and absorption of irrigation fluid with possible TUR syndrome cannot be ignored.

With bipolar systems, one tries to counter the problems associated with conventional monopolar systems by allowing resection in an iso-osmotic saline solution and obviating the use of a return electrode applied to the skin because the active and return electrode are placed on the same axis on the resectoscope.

Many studies have reported the advantages and disadvantages of bipolar resection in $\mathrm{BPH}$ patients [24-33]. Our group compared the Olympus TURIS device over conventional monopolar resections in $238 \mathrm{BPH}$ patients [23]. In the bipolar resection group there were only 4 clot retentions (3.4\%) and no occurrence of TUR syndrome. But staff members as well as trainees needed more operative time with the bipolar system. We do not discard the importance of the learning curve, but prolonged operative time was also related to specific TURIS characteristics such as the size of the resection loop and smaller endoscopes [33].

To date, no studies have analysed the advantages and disadvantages of bipolar resection in prostate cancer patients. Therefore, we reanalysed our data retrospectively. Two important factors were investigated. Did bipolar resection have a positive influence on the electrolyte balance in this older and debilitated patient group, and was bipolar resection associated with less prostate bleeding after the procedure?

In the present study we did not observe statistically significant changes in the electrolyte balances, although this advantage was clear in $\mathrm{BPH}$ patients. Possible explanations for this are the smaller study groups, the shorter operation times 
in patients with prostate cancer, and the fact that in palliative resections one does not need to go as close to the surgical capsule of the prostate because the creation of a voiding channel is sufficient.

Surprisingly, there was a $12 \%$ clot retention rate in the bipolar resection group. However, this is not a statistically significant difference from the conventional monopolar group. Recent experimental work by Qu et al. reported significantly better haemostasis with the bipolar technique of the Gyrus PlasmaKinetic system (Gyrus Medical Ltd, UK) in an isolated normal saline perfused porcine kidney [34]. The coagulation depth with bipolar technology is sufficient to seal blood vessels of $125 \mu \mathrm{m}$ diameter, which is not possible with monopolar devices. Such vessels are only present in $0.1 \%$ of benign prostate hyperplastic tissue.

In the majority (79\%) of patients undergoing palliative endoscopic resection, the tumour was pathologically upgraded. Potential explanations for this phenomenon are grade progression with time, effects of hormonal deprivation, and achievement of a hormone refractory state. Civantos et al. pointed out that prolonged hormonal deprivation induces histological changes in prostate cancer that may be incorrectly interpreted as high-grade disease [35].

In conclusions, urethral obstruction by prostate cancer is initially treated by hormonal deprivation and drained by a suprapubic or urethral catheter. Endoscopic resection is a valuable therapeutic option when hormonal manipulation fails or when there is hormone refractory disease. Effective relief of the obstruction is possible with an acceptable rate of procedure-related side effects. In this specific setting, bipolar technology offers no substantial benefit over conventional monopolar technology.

\section{References}

1. Madersbacher S, Lackner J, Brössner C, et al. Reoperation, myocardial infarction and mortality after transurethral and open prostatectomy: a nation-wide, long-term analysis of 23,123 cases. Eur Urol 2005; 47: 499-504.

2. Rassweiler J, Teber D, Kuntz R, Hofmann R. Complications of transurethral resection of the prostate (TURP) incidence, management, and prevention. Eur Urol 2006; 50: 969-79.

3. Miki M, Loritani N. TUR in saline: TURis. Publisher Olympus Corporation, Tokyo, Japan, 2004.

4. Mamoulakis C, Trompetter M, de la Rosette J. Bipolar transurethral resection of the prostate: the "golden standard" reclaims its leading position. Curr Opin Urol 2009; 19: 26-32.

5. Mamoulakis C, Ubbink DT, de la Rosette JJ. Bipolar versus monopolar transurethral resection of the prostate: a systematic review and meta-analysis of randomized controlled trials. Eur Urol 2009; 56: 798-809
6. Moul JW, Davis R, Vaccaro JA, Sihelnik SA, Belville WD, McLeod DG. Acute urinary retention associated with prostatic carcinoma. J Urol 1989; 141: 1375-7.

7. Oefelin MG. Prognostic significance of obstructive uropathy in advanced prostate cancer. Urology 2004; 63: 1117-21.

8. Thomas DJ, Balaji VJ, Coptcoat MJ, Abercrombie GF. Acute urinary retention secondary to carcinoma of the prostate. Is initial channel TURP beneficial? J R Soc Med 1992; 85: 318-9.

9. Carpentier PJ, Schröder FH. Transrectal ultrasonography in the follow-up of prostatic carcinoma patients: a new prognostic parameter? J Urol 1984; 131: 903-5.

10. Fleischmann JD, Catalona WJ. Endocrine therapy for bladder outlet obstruction from carcinoma of the prostate. J Urol 1985; 134: 498-500.

11. Varenhorst E, Alund G. Urethral obstruction secondary to carcinoma of prostate: response to endocrine treatment. Urology 1985; 25: 354-6.

12. Mazur AW, Thompson IM. Efficacy and morbidity of “channel” TURP. Urology 1991; 38: 526-28.

13. Crain DS, Amling CL, Kane CJ. Palliative transurethral prostate resection for bladder outlet obstruction in patients with locally advanced prostate cancer. J Urol 2004; 171: 668-71.

14. Engelhardt PF, Reidl CR, Crain DS, Amling CL, Kane CJ. Palliative transurethral prostate resection for bladder outlet obstruction in patients with locally advanced prostate cancer. J Urol 2004; 171: 668-71.

15. Fadlon EJ, Rees RC, McIntyre C, Sharrard RM, Lawry J, Hamdy FC. Detection of circulating prostate-specific antigen-positive cells in patients with prostate cancer by flow cytometry and reverse transcription polymerase chain reaction. Br J Cancer 1996; 74: 400-5.

16. Hanks GE, Leibel S, Kramer S. The dissemination of cancer by transurethral resection of locally advanced prostate cancer. J Urol 1983; 129: 309-11.

17. Kuban DA, el-Mahadi AM, Schellhammer PF, Babb TJ. The effect of transurethral prostatic resection on the incidence of osseous prostatic metastasis. Cancer 1985; 56: 961-4.

18. Forman JD, Order SE, Zinreich ES, Lee DJ, Wharam MD, Mellits ED. The correlation of pretreatment transurethral resection of prostatic cancer with tumor dissemination and disease-free survival. A univariate and multivariate analysis. Cancer 1986; 58: 1770-8.

19. Sandler HM, Hanks GE. Analysis of the possibility that transurethral resection promotes metastasis in prostate cancer. Cancer 1988; 62: 2622-7.

20. Hübner W, Engelhardt P, Riedl C, Häusler N, Pflüger H. Negative influence of the TURP on the clinical outcome in patients with obstructive prostate carcinoma and possible alternative. Aktuel Urol 1999; 30: 4-9.

21. Anast JW, Andriole GL, Grubb RL 2nd. Managing the local complications of locally advanced prostate cancer. Curr Urol Rep 2007; 8: 211-6.

22. Madersbacher S, Marberger M. Is transurethral resection of the prostate still justified? BJU Int 1999; 83: 227-37.

23. Kellow NH. Pacemaker failure during transurethral resection of the prostate. Anaesthesia 1993; 48: 136-8.

24. Starkman JS, Santucci RA. Comparison of bipolar transurethral resection of the prostate with standard transurethral prostatectomy: shorter stay, earlier catheter removal and fewer complications. BJU Int 2005; 95: 69-71.

25. Tefekli A, Muslumanoglu AY, Baykal M, Binbay M, Tas A, Altunrende $F$. A hybrid technique using bipolar energy in transurethral prostate resection: a prospective, randomized comparison. J Urol 2005; 174: 1339-943. 
26. Seckiner I, Yesilli C, Akduman B, Altan K, Mungan NA. A prospective randomized study for comparing bipolar plasmakinetic resection of the prostate with standard TURP. Urol Int 2006; 76: 139-43.

27. Ho HS, Yip SK, Lim KB, Fook S, Foo KT, Cheng CW. A prospective randomized study comparing monopolar and bipolar transurethral resection of prostate using transurethral resection in saline (TURIS) system. Eur Urol 2007; 52: 517-22.

28. Yoon CJ, Kim JY, Moon KH, Jung HC, Park TC. Transurethral resection of the prostate with a bipolar tissue management system compared to conventional monopolar resectoscope: one-year outcome. Yonsei Med J 2006; 47: 715-20.

29. Che XY, Song XS, Wu DJ, Wang FP, Wang QF, Wang JB. Transurethral prostatectomy with the bipolar plasmakinetic technique for benign prostate hyperplasia: a report of 712 cases. Zhonghua Nan ke Xue 2009; 15: 449-51.

30. Autorino R, Damiano R, Di Lorenzo G, et al. Four-year outcome of a prospective randomised trial comparing bipolar plasmakinetic and monopolar transurethral resection of the prostate. Eur Urol 2009; 55: 922-9.

31. Puppo P, Bertolotto F, Introini C, Germinale F, Timossi L, Naselli A. Bipolar transurethral resection in saline (TURis): outcome and complication rates after the first 1000 cases. J Endourol 2009; 23: 1145-9.

32. Fagerström T, Nyman CK, Hahn RG. Bipolar transurethral resection of the prostate causes less bleeding than the monopolar technique: a single centre randomized trial of 202 patients. BJU Int 2010; 105: 1560-4.

33. Michielsen DP, Debacker T, De Boe V, et al. Bipolar transurethral resection in saline - an alternative surgical treatment for bladder outlet obstruction. J Urol 2007; 178: 2035-9.

34. Qu L, Wang X, Huang X, Zhang Y, Zeng X. Use of a novel ex-vivo model to compare the hemostatic properties of plasmakinetic resection, transurethral vaporisation resection and conventional transurethral resection of the prostate. Urology 2007; 70: 1034-8.

35. Civantos F, Soloway MS, Pinto JE. Histopathological effects of androgen deprivation in prostatic cancer. Semin Urol Oncol 1996; 14: 22-31. 